\title{
A survey of the nutritional and haemagglutination properties of legume seeds generally available in the UK
}

\author{
BY GEORGE GRANT, LINDA J. MORE, NORMA H. MCKENZIE, \\ JAMES C. STEWART AND ARPAD PUSZTAI \\ The Rowett Research Institute, Bucksburn, Aberdeen AB2 9SB
}

(Received 21 September 1982 - Accepted 29 April 1983)

\begin{abstract}
1. Eighty-five samples from fifteen different legume seed lines generally available in the UK were examined by measurements of their net protein utilization by rats and by haemagglutination tests with erythrocytes from a number of different animal species. From these results the seeds were classified into four broad groups.

2. Group a seeds from most varieties of kidney (Phaseolus vulgaris), runner (Phaseolus coccineus) and tepary (Phaseolus acutifolius) beans showed high reactivity with all cell types and were also highly toxic.

3. Group $b$, which contained seeds from lima or butter beans (Phaseolus lunatus) and winged bean (Psophocarpus tetragonolobus), agglutinated only human and pronase-treated rat erythrocytes. These seeds did not support proper growth of the rats although the animals survived the $10 \mathrm{~d}$ experimental period.

4. Group $c$ consisted of seeds from lentils (Lens culinaris), peas (Pisum sativum), chick-peas (Cicer arietinum), blackeyed peas (Vigna sinensis), pigeon peas (Cajanus cajan), mung beans (Phaseolus aureus), field or broad beans (Vicia faba) and aduki beans (Phaseolus angularis). These generally had low reactivity with all cells and were non-toxic.

5. Group $d$, represented by soya (Glycine max) and pinto (Phaseolus vulgaris) beans, generally had low reactivity with all cells but caused growth depression at certain dietary concentrations. This growth depression was probably mainly due to antinutritional factors other than lectins.

6. Lectins from group $a$ seeds showed many structural and immunological similarities. However the subunit composition of the lectin from the tepary bean samples was different from that of the other bean lectins in this or any other groups.
\end{abstract}

The seeds of many edible legumes have long been known to contain proteins which agglutinate erythrocytes (Boyd, 1963). Some of these haemagglutinins (lectins) have been suggested to contribute to the poor nutritive quality of raw beans (Jaffe, 1969). Thus certain lines of kidney bean (Phaseolus vulgaris) are known to be toxic to human beings (Greibel, 1950; Noah et al. 1980), rats (Evans et al. 1974) and quail (Coturnix coturnix japonica) (Jayne-Williams \& Burgess, 1974). The toxic factor in a sample of kidney beans has been shown to be identical with its constituent lectins and, consequently, the level of toxicity is directly related to the lectin content and hence haemagglutinating activity (Pusztai \& Palmer, 1977).

Lectins from different seeds show an extent of specificity in their activity towards human and various animal erythrocytes (Landsteiner \& Raubitschek, 1908). Thus a possible classification of the lectins present in different lines of kidney bean into four types has been suggested (Jaffe et al. 1972); of these only two types, namely those that exhibit activity towards trypsinated cow erythrocytes, are toxic (Jaffe, 1980).

However, it is not known how far these findings may be generalized. To find out whether the low nutritional performance of legume seeds can be directly attributed to their lectin content or if the haemagglutinating activity towards trypsinated cow erythrocytes can be used as an indicator of toxicity a general survey was undertaken of the agglutinin activity against a number of cells of different origin and the nutritional properties of untreated seeds commercially available in the UK. 
Table 1. Comparison of the net protein utilization (NPU) values of legume

\begin{tabular}{|c|c|c|c|c|c|c|c|c|}
\hline \multirow[b]{3}{*}{ Group } & \multirow[b]{3}{*}{ Sample } & \multirow{3}{*}{$\begin{array}{c}\text { Number } \\
\text { of } \\
\text { samples }\end{array}$} & \multirow{2}{*}{\multicolumn{2}{|c|}{ Nitrogen (g/kg) }} & \multicolumn{4}{|c|}{ NPU } \\
\hline & & & & & \multicolumn{2}{|c|}{$\begin{array}{l}\text { Diet containing } \\
50 \mathrm{~g} \text { sample-protein } \\
+50 \mathrm{~g} \text { casein } / \mathrm{kg}\end{array}$} & \multicolumn{2}{|c|}{$\begin{array}{l}\text { Diet containing } \\
100 \mathrm{~g} \text { sample- } \\
\text { protein } / \mathrm{kg}\end{array}$} \\
\hline & & & Average & Range* & Average & Range & Average & Range \\
\hline \multirow[t]{5}{*}{$a$} & $\begin{array}{l}\text { Runner bean } \\
\text { (Phaseolus coccineus) }\end{array}$ & 5 & $37 \cdot 7$ & $34.4-38 \cdot 9$ & 5 & $2-10$ & -- & $\begin{array}{l}\text { Negative } \\
\text { Rats died } \|\end{array}$ \\
\hline & $\begin{array}{l}\text { Red or brown kidney bean } \\
\text { (Phaseolus vulgaris) }\end{array}$ & 10 & $40 \cdot 3$ & $36 \cdot 0-44 \cdot 0$ & - & Negative $\neq-14$ & - & $\begin{array}{l}\text { Negative } \\
\text { Rats died }\end{array}$ \\
\hline & $\begin{array}{l}\text { White kidney bean } \\
\text { (Phaseolus vulgaris) }\end{array}$ & 4 & $42 \cdot 4$ & $39 \cdot 8-44 \cdot 0$ & 17 & $4-36$ & - & $\begin{array}{l}\text { Negative } \\
\text { Rats died }\end{array}$ \\
\hline & $\begin{array}{l}\text { Black kidney bean } \\
\text { (Phaseolus vulgaris) }\end{array}$ & 5 & $42 \cdot 2$ & $40 \cdot 9-43 \cdot 9$ & 12 & $10-16$ & - & $\begin{array}{l}\text { Negative } \\
\text { Rats died }\end{array}$ \\
\hline & $\begin{array}{l}\text { Tepary bean } \\
\text { (Phaseolus acutifolius) }\end{array}$ & 4 & $51 \cdot 3$ & $50 \cdot 0-52 \cdot 8$ & 10 & $8-13$ & - & $\begin{array}{l}\text { Rats died } \\
\text { Rats died }\end{array}$ \\
\hline \multirow[t]{2}{*}{$b$} & $\begin{array}{l}\text { Winged bean } \\
\text { (Psophocarpus tetragonolobus) }\end{array}$ & 2 & $67 \cdot 4$ & $66 \cdot 0-68 \cdot 8$ & 25 & $24-26$ & - & $\begin{array}{l}\text { Negative } \\
\text { Negative }\end{array}$ \\
\hline & $\begin{array}{l}\text { Baby lima bean } \\
\text { (Phaseolus lunatus) }\end{array}$ & 1 & $39 \cdot 2$ & & 27 & & Negative & \\
\hline \multirow[t]{9}{*}{$c$} & $\begin{array}{l}\text { Lentils } \\
\text { (Lens esculentus) }\end{array}$ & 7 & $47 \cdot 5$ & $44 \cdot 3-49 \cdot 6$ & 53 & $49-55$ & 44 & $43-46$ \\
\hline & $\begin{array}{l}\text { Peas } \\
\text { (Pisum sativum) }\end{array}$ & 5 & $45 \cdot 5$ & $40 \cdot 9-49 \cdot 1$ & 60 & $54-66$ & 52 & $43-62$ \\
\hline & $\begin{array}{l}\text { Chick peas } \\
\text { (Cicer arietinum) }\end{array}$ & 7 & $38 \cdot 7$ & $38 \cdot 1-39 \cdot 3$ & 66 & $66-66$ & 56 & $53-58$ \\
\hline & $\begin{array}{l}\text { Blackeyed peas } \\
\text { (Vigna sinensis) }\end{array}$ & 7 & $42 \cdot 3$ & $42 \cdot 2-42 \cdot 4$ & 59 & $55-62$ & 37 & $37-37$ \\
\hline & $\begin{array}{l}\text { Pigeon peas } \\
\text { (Cajanus cajan) }\end{array}$ & 1 & $34 \cdot 9$ & & 60 & & 50 & \\
\hline & $\begin{array}{l}\text { Mung beans } \\
\text { (Phaseolus aureus) }\end{array}$ & 6 & 4.04 & $37 \cdot 9-42 \cdot 4$ & 69 & $68-69$ & 44 & $44-44$ \\
\hline & $\begin{array}{l}\text { Black mung beans } \\
\text { (Phaseolus aureus) }\end{array}$ & 1 & $38 \cdot 5$ & & 60 & & 35 & \\
\hline & $\begin{array}{l}\text { Field or broad beans } \\
\text { (Vicia faba) }\end{array}$ & 9 & $48 \cdot 7$ & $41 \cdot 0-55 \cdot 2$ & 59 & $52-68$ & 48 & $39-57$ \\
\hline & $\begin{array}{l}\text { Aduki beans } \\
\text { (Phaseolus angularis) }\end{array}$ & 1 & 41.9 & & 53 & & 39 & \\
\hline \multirow[t]{2}{*}{$d$} & $\begin{array}{l}\text { Soya beans } \\
\text { (Glycine max) }\end{array}$ & 6 & 67.5 & $64 \cdot 8-70 \cdot 1$ & 56 & $53-58$ & 24 & $19-28$ \\
\hline & $\begin{array}{l}\text { Pinto beans } \\
\text { (Phaseolus vulgaris) }\end{array}$ & 4 & $40 \cdot 6$ & $39 \cdot 1-42 \cdot 1$ & 50 & $45-55$ & 10 & $9-11$ \\
\hline
\end{tabular}

Results for multiple samples are expressed as averages (arithmetic average) except for the haemagglutination activities where values were approximated to the nearest actual dilution value.

* The range is expressed in terms of the minimum and maximum values obtained.

\section{MATERIALS AND METHODS}

Seed samples

Samples of lentils (Lens culinaris), peas (Pisum sativum), chickpeas (Cicer arietinum), blackeyed pea (Vigna sinensis), pigeon pea (Cajanus cajan), mung bean (Phaseolus aureus), field, broad, ful or tic beans (Vicia faba), soya bean (Glycine max), aduki bean (Phaseolus 
seeds and their haemagglutination activity towards various erythrocytes

\begin{tabular}{|c|c|c|c|c|c|c|c|c|c|}
\hline \multicolumn{10}{|c|}{ Haemagglutination activity } \\
\hline \multirow{2}{*}{\multicolumn{2}{|c|}{$\begin{array}{l}\text { Rabbit blood } \\
\text { cells }\end{array}$}} & \multirow{2}{*}{\multicolumn{2}{|c|}{$\begin{array}{l}\text { Pronase-treated } \\
\text { rat blood cells }\end{array}$}} & \multirow{2}{*}{\multicolumn{2}{|c|}{$\begin{array}{l}\text { Trypsin-treated } \\
\text { cow blood cells }\end{array}$}} & \multicolumn{4}{|c|}{ Human blood cells } \\
\hline & & & & & & \multicolumn{2}{|r|}{$0^{+}$} & \multicolumn{2}{|r|}{$\mathrm{AB}^{+}$} \\
\hline Average & Range & Average & Range & Average & Range & Average & Range & Average & Range \\
\hline 6 & $1 \cdot 5-12$ & 1.5 & $0 \cdot 8-1 \cdot 5$ & 6 & $3-12$ & 195 & $98-390$ & 195 & $98-390$ \\
\hline$\dagger$ & $6-98$ & 1.5 & $0.4-6$ & $\dagger$ & $1 \cdot 5-98$ & 195 & $98-390$ & 195 & $98-390$ \\
\hline 12 & $6-24$ & 6 & $1 \cdot 5-12$ & $\dagger$ & $3-780$ & 195 & $98-390$ & $\dagger$ & $12-390$ \\
\hline 12 & $6-24$ & 3 & $1 \cdot 5-6$ & $\dagger$ & $1 \cdot 5-49$ & $\dagger$ & $24-390$ & $\dagger$ & $24-390$ \\
\hline 6 & $1 \cdot 5-12$ & $1 \cdot 5$ & $0 \cdot 8-1 \cdot 5$ & 195 & $49-390$ & 98 & $24-195$ & 24 & $24-24$ \\
\hline 12500 & $12500-12500$ & 24 & $24-24$ & 12500 & $12500-12500$ & 390 & $195-780$ & 195 & $195-195$ \\
\hline 12500 & & 6 & & 12500 & & 12500 & & 98 & \\
\hline$\dagger$ & $49-780$ & 24 & $6-49$ & 12500 & $12500-12500$ & 3120 & $780-3120$ & 3120 & $1560-6250$ \\
\hline 98 & $49-195$ & 24 & $12-49$ & 12500 & $12500-12500$ & 3120 & $3120-3120$ & 3120 & $3120-3120$ \\
\hline 12500 & $12500-12500$ & $\dagger$ & $98-1560$ & 12500 & $6250-12500$ & 12500 & $12500-12500$ & 12500 & $12500-12500$ \\
\hline 12500 & $12500-12500$ & $\dagger$ & $98-1560$ & 12500 & $12500-12500$ & 12500 & $12500-12500$ & 12500 & $12500-12500$ \\
\hline 12500 & & 98 & & 12500 & & 12500 & & 12500 & \\
\hline 12500 & $12500-12500$ & 1560 & $390-3120$ & 12500 & $12500-12500$ & 12500 & $12500-12500$ & 12500 & $12500-12500$ \\
\hline 12500 & & 24 & & 12500 & & 12500 & & 12500 & \\
\hline+ & $49-3120$ & $\dagger$ & $24-780$ & 12500 & $3120-12500$ & 6250 & $3120-12500$ & 6250 & $3120-12500$ \\
\hline 12500 & & 24 & & 3120 & & & 12500 & 12500 & \\
\hline$\dagger$ & $24-390$ & 390 & $195-390$ & 3120 & $3120-3120$ & 12500 & $12500-12500$ & 12500 & $12500-12500$ \\
\hline 12500 & $6250-12500$ & 98 & $49-98$ & 6250 & $3120-6250$ & 12500 & $12500-12500$ & 12500 & $12500-12500$ \\
\hline
\end{tabular}

$\dagger$ Where the range of the haemagglutinin was much greater than the experimental error only minimum and maximum values obtained from different samples are given.

$\ddagger$ NPU value was less than 0 .

\| The experiment had to be terminated within the $10 \mathrm{~d}$ period because the rats died.

angularis), runner bean (Phaseolus coccineus), lima or butter bean (Phaseolus lunatus), zebra bean (Phaseolus zebra) and of various kidney beans (Phaseolus vulgaris) were obtained from Aberdeen Grain and Herb Store (Aberdeen), Nature's Larder (Aberdeen), Real Foods (Edinburgh) and Fine Fare (Aberdeen). Black mung beans were obtained from Abrosia (Aberdeen). The winged bean (Psophocarpus tetragonolobus) and tepary bean (Phaseolus 
acutifolius) samples were provided by the Mayaguez Institute of Tropical Agriculture (Puerto Rico), the Phaseolus coccineus, Phaseolus leucanthius and Phaseolus lunatus samples by the National Vegetable Research Station (Wellesbourne, Warwick) and the sultani bean and various broad bean samples by the Rowett Research Institute (Aberdeen). Lacticunextracted casein was supplied by Glaxo Laboratories Ltd (Greenford, Middlesex).

\section{Diets}

Diets were prepared as described previously (Palmer et al. 1973) and contained a total of $100 \mathrm{~g}$ protein as casein or uncooked seed protein $/ \mathrm{kg}$ or a combination of casein plus seed protein each at $50 \mathrm{~g} / \mathrm{kg}$. The protein sources were given without supplementation with any individual amino acids.

\section{Haemagglutination assay}

Blood samples were collected into preheparinized tubes and after collection were diluted twentyfold with saline $(9 \mathrm{~g}$ sodium chloride $/ 1)$. Rat erythrocytes were pretreated with pronase $\left(0.2 \mathrm{mg} / 10 \mathrm{ml}\right.$ diluted erythrocytes for $30 \mathrm{~min}$ at $\left.25^{\circ}\right)$ and cow erythrocytes with trypsin $\left(0 \cdot 1 \mathrm{mg} / 10 \mathrm{ml}\right.$ diluted erythrocytes for $60 \mathrm{~min}$ at $\left.25^{\circ}\right)$ (Jaffe et al. 1972). Samples were visually sorted to ensure purity and then ground in a Wiley Laboratory Mill fitted with a $425 \mu \mathrm{m}$ mesh grid. Flours were extracted with $0.04 \mathrm{M}$-sodium borate buffer, pH $8 \cdot 0$, for $16 \mathrm{~h}$ at $1^{\circ}$ (flour-buffer $1: 20, \mathrm{w} / \mathrm{v}$ ). After centrifugation $(78000 \mathrm{~g}$ for $60 \mathrm{~min}$ ), the clear supernatant fractions were tested for haemagglutinin activity. The supernatant fractions were serially diluted using a Titertek medimixer (Flow Laboratories Ltd, Irvine) and mixed with an equal volume of diluted erythrocytes (final volume $0 \cdot 1 \mathrm{ml}$ ). This gave the following sample concentrations $(\mu \mathrm{g} / \mathrm{ml})$ in the haemagglutinin assay:

$\begin{array}{lrrrrrrrrr}\text { Tube no.... } & 1 & 2 & 3 & 4 & 5 & 6 & 7 & 8 & 9 \\ & 12500 & 6250 & 3120 & 1560 & 780 & 390 & 195 & 98 & 49 \\ \text { Tube no... } & 10 & 11 & 12 & 13 & 14 & 15 & 16 & 17 & 18 \\ & 24 & 12 & 6 & 3 & 1 \cdot 5 & 0 \cdot 8 & 0 \cdot 4 & 0 \cdot 2 & 0 \cdot 1\end{array}$

The mixed samples were left for $16 \mathrm{~h}$ and then the amount of clumping was assessed by microscope. Phaseolus vulgaris var. Processor and var. Pinto III extracts (Pusztai et al. 1979) were included in each assay as standard controls. One unit of haemagglutination activity (H.U.) was defined as the amount of material per $\mathrm{ml}$ in the last dilution giving $50 \%$ agglutination. For comparison purposes, the activity of the various samples was given as the amount of material $(\mu \mathrm{g})$ containing 1 H.U. The limits of experimental accuracy for this technique are \pm 1 dilution and therefore samples of low or moderate haemagglutinin activity will have an apparently-wide range of error. For example, a sample with a titre of 6250 will have a range of accuracy of 12500-3120. The results for multiple samples were combined to produce an arithmetic average but because of the experimental error and, for comparison purposes, any value which was not equivalent to one of the sample concentrations used, was rounded up to the nearest actual value. For example, the average of 12500 and 6250 was given as 12500 .

\section{Nutritional evaluation}

Net protein utilization (NPU) was determined by a method (Palmer et al. 1973) based on that described by Miller \& Bender (1955).

\section{Chemical analyses}

Diets, carcass and ground faeces samples were analysed for moisture content and total nitrogen (Davidson et al. 1970). Sodium dodecyl sulphate (SDS)-polyacrylamide gel electrophoresis was carried out on slabs of $17.6 \%$ polyacrylamide separation gel and $4 \%$ 
Table 2. Comparison of the net protein utilization (NPU) values and haemagglutinating activity towards various erythrocytes of the lima or butter bean (Phaseolus lunatus) and runner bean (Phaseolus coccineus) samples

\begin{tabular}{|c|c|c|c|c|c|c|c|c|}
\hline \multirow[b]{3}{*}{ Sample } & \multirow{3}{*}{$\begin{array}{c}\text { Nitrogen } \\
(\mathrm{g} / \mathrm{kg})\end{array}$} & \multicolumn{2}{|c|}{ NPU } & \multicolumn{5}{|c|}{ Haemagglutination activity } \\
\hline & & \multirow{2}{*}{$\begin{array}{c}\text { Diet containing } \\
50 \mathrm{~g} \text { sample- } \\
\text { protein }+50 \mathrm{~g} \\
\text { casein } / \mathrm{kg}\end{array}$} & \multirow{2}{*}{$\begin{array}{c}\text { Diet containing } \\
100 \mathrm{~g} \text { sample- } \\
\text { protein } / \mathrm{kg}\end{array}$} & \multirow{2}{*}{$\begin{array}{c}\text { Rabbit } \\
\text { blood } \\
\text { cells }\end{array}$} & \multirow{2}{*}{$\begin{array}{l}\text { Pronase- } \\
\text { treated } \\
\text { rat blood } \\
\text { cells }\end{array}$} & \multirow{2}{*}{$\begin{array}{l}\text { Trypsin- } \\
\text { treated } \\
\text { cow blood } \\
\text { cells }\end{array}$} & \multicolumn{2}{|c|}{$\begin{array}{l}\text { Human } \\
\text { blood } \\
\text { cells }\end{array}$} \\
\hline & & & & & & & $0^{+}$ & $\mathrm{AB}^{+}$ \\
\hline Runner bean & $40 \cdot 4$ & ND & ND & 49 & 3 & 49 & 195 & 195 \\
\hline Lima beans: 1 & $34 \cdot 1$ & 17 & Rats died $\dagger$ & 49 & 0.8 & 6 & 195 & 390 \\
\hline 2 & $31 \cdot 0$ & 3 & Rats died & 3 & $1 \cdot 5$ & $1 \cdot 5$ & 49 & 98 \\
\hline 3 & $31 \cdot 0$ & 47 & 15 & 12500 & 24 & 6250 & 12500 & 1560 \\
\hline Baby lima beans & $39 \cdot 2$ & 27 & Negative* & 12500 & 6 & 12500 & 12500 & 98 \\
\hline Butter beans: 1 & 35.8 & 42 & Negative & 12500 & 49 & 12500 & 12500 & 98 \\
\hline 2 & $34 \cdot 9$ & 44 & 9 & 12500 & 1.5 & 3120 & 12500 & 780 \\
\hline Lima bean & $37 \cdot 3$ & ND & ND & 12500 & 12 & 6250 & 12500 & 780 \\
\hline
\end{tabular}

ND, not determined.

* NPU value was less than 0 .

$\uparrow$ The experiment had to be terminated within the $10 \mathrm{~d}$ experimental period because the rats died.

stacking gel (Laemmli, 1970) run on an LKB Multiphor apparatus. The samples were extracted with SDS $(20 \mathrm{~g} / 1)$, 2-mercaptoethanol $(10 \mathrm{ml} / 1)$ to give a nominal concentration of $2.5-3.0 \mathrm{~g}$ protein/1. After heating at $100^{\circ}$ for $15 \mathrm{~min}, 10 \mu \mathrm{l}$ of each sample was applied to the polyacrylamide gel and run for $4 \mathrm{~h}$ at $2.1 \mathrm{~mA} /$ well. The gels were stained with a Coomassie Blue solution $(5 \mathrm{~g} / 1)$ and destained with a solvent mixture of methanol-acetic acid-water ( $8: 1: 8$, by vol.).

\section{RESULTS}

On the basis of nutritional value and behaviour towards lectins (Table 1), the seeds fell into four broad groups.

Group $a$, which comprised red or brown, black and white kidney beans, runner beans and tepary beans, gave low NPU values $(0-17)$ with mixed diets containing $50 \mathrm{~g}$ seed protein and $50 \mathrm{~g}$ casein $/ \mathrm{kg}$; furthermore, with diets containing $100 \mathrm{~g}$ seed protein $/ \mathrm{kg}$, negative NPU values were obtained or, in most cases, the rats died within the $10 \mathrm{~d}$ experimental period. These samples were therefore classed as highly toxic.

Group $b$, comprising winged beans and lima or butter beans, depressed growth with both diets. In mixed diets containing $50 \mathrm{~g}$ seed protein and $50 \mathrm{~g}$ casein $/ \mathrm{kg}$, NPU values of $25-27$ were obtained whilst at $100 \mathrm{~g}$ seed protein $/ \mathrm{kg}$ the corresponding NPU varied between negative and slightly positive values. In all cases, the rats survived the $10 \mathrm{~d}$ experimental period.

Group $c$, including lentils, peas, chick-peas, blackeyed peas, pigeon peas, mung beans, black mung beans, field or broad beans and aduki beans, gave good NPU values with both diets. With diets containing $50 \mathrm{~g}$ seed protein plus $50 \mathrm{~g}$ casein $/ \mathrm{kg}$ average NPU values of 50-70 were obtained. At $100 \mathrm{~g}$ seed protein $/ \mathrm{kg}$ the corresponding values were $35-56$. These samples were therefore considered to be essentially non-toxic.

Group $d$, represented by soya and pinto beans, gave positive NPU values at both 50 and $100 \mathrm{~g} / \mathrm{kg}$, but whilst at $50 \mathrm{~g}$ seed protein $/ \mathrm{kg}$ average NPU values of $50-56$ were obtained, those at $100 \mathrm{~g}$ seed protein $/ \mathrm{kg}$ were considerably lower at 24 (soya bean) and 10 (pinto bean). 
Subdivision on the basis of nutritional performance correlated well with the erythrocyte specificities (Landsteiner \& Raubitschek, 1908) of the seed constituent lectins. Group $a$ samples had high lectin activities and agglutinated all the erythrocytes tested, group $b$ agglutinated pronase-treated rat erythrocytes and human $\mathrm{O}^{+}$or $\mathrm{AB}^{+}$erythrocytes or both and group $c$ agglutinated only rabbit or pronase-treated rat erythrocytes or both.

The results of the nutritional evaluation and haemagglutinating activity measurements obtained with various lima and butter bean samples were not clear (Table 2). Although the lima bean (Phaseolus lunatus) lectin is known to be blood-group specific for human $\mathrm{A}^{+}$ erythrocytes (Jaffe, 1980), only four of the lima and butter bean samples of the six tested showed this type of specificity. These samples also gave intermediate NPU values indicating they were group $b$ seeds. However, the other two lima bean samples reacted with all the erythrocytes tested, gave very low NPU values with $50 \mathrm{~g} / \mathrm{kg}$ diets and with $100 \mathrm{~g} / \mathrm{kg}$ diets the rats died during the experiment. This indicated they were group $a$ seeds. Indeed, it was shown by SDS-polyacrylamide gel electrophoresis (Plate 1) that the subunit composition of these two lima bean samples was more similar to the more toxic runner bean than to that of genuine lima bean samples.

These results may have been due to incorrect labelling; other examples of incorrect labelling of seeds were also encountered. For example, some samples of pinto beans were found to be similar to the more toxic rose-cocoa (crab-eye) beans and a sample, sold as white kidney bean, was found to contain at least three different bean types.

\section{DISCUSSION}

Legume seeds could be separated into four broad groups. Within these groups the nutritional performance or the extent of toxicity of the seeds could be related to the general reactivity and the lectin content of the seed.

With group $a$ and group $b$ samples there was a good correlation between lectin content, specificity and NPU values; thus it was considered that group $a$ samples exhibited a high extent of lectin-related toxicity and group $b$ samples an intermediate extent of lectin-related toxicity. With group $c$ samples there was no such correlation and these were considered to show no appreciable lectin-related toxic effects.

Although no single erythrocyte type could be used as an indicator, the potential lectin-related toxicity of seed samples could be predicted by measuring the haemagglutinating activity towards various erythrocytes. Thus, since group $d$ samples failed to give a clear correlation between lectin content and NPU values and they agglutinated only rabbit or pronase-treated rat erythrocytes or both, it is suggested that other antinutritional factors might be mainly responsible for the growth depression found with diets containing these samples at $100 \mathrm{~g}$ seed-protein $/ \mathrm{kg}$.

With several of the seeds examined such as chick-peas, blackeyed peas, field or broad beans, soya beans and mung beans, the range of haemagglutinin activities found for individual batches of the seeds was somewhat greater than the experimental error. Since the values obtained for individual batches were reproducible, within experimental error, it was considered that these differences were a true reflection of the variability between commercial batches available in the UK.

The possibility of contamination of the commercial samples either by other seed species or by chemical and biological materials cannot be completely excluded.

It has previously been noted that of the group $a$ samples the kidney (Phaseolous vulgaris) and runner (Phaseolus coccineus) beans are immunologically closely related, although not identical (Pusztai et al. 1983). However, the tepary bean (Phaseolus acutifolius) is the most distantly related of the group $a$ beans (Pusztai et al. 1983). This was further supported by 
the results obtained by SDS-polyacrylamide gel electrophoresis (Plate 1). Whilst kidney, runner and zebra beans gave patterns indicating molecular weights of approximately 30000 for the lectin subunit bands, no major bands were seen in corresponding positions with the tepary bean samples, thus indicating that the tepary bean lectin might be somewhat different from the other lectins within the group. This finding also suggested that similar nutritional effects or haemagglutinating reactivity of the different bean samples did not necessarily imply similarity in the identity of composition or structure of their constituent lectins.

The differences found with lima bean samples highlight the problem that many beans have similar markings and are of similar colour, size and shape and it cannot be guaranteed that seeds generally available will always be labelled with their correct botanical name. Therefore, whilst it is clear that a number of legume seeds are non-toxic, in practice all beans should be treated as potentially toxic, because of the problem of identification. Thus seeds should be fully hydrated and heated at $100^{\circ}$ for a minimum of $10 \mathrm{~min}$ before use (Grant et al. 1982).

This work was in part supported by a grant from the Scottish Home and Health Department. The authors thank Dr L. Telek of the Mayaguez Institute of Tropical Agriculture, Dr N. L. Innes of the National Vegetable Research Station and Dr V. F. Fowler of the Rowett Research Institute for the supply of various seed samples.

\section{REFERENCES}

Boyd, W. C. (1963). Vox Sanguinis 8, 1-32.

Davidson, J., Mathieson, J. \& Boyne, A. W. (1970). Analyst 95, 181-193.

Evans, R. J., Pusztai, A., Watt, W. B. \& Bauer, D. H. (1974). Biochimica Biophysica Acta 303, $175-184$.

Grant, G., More, L. J., McKenzie, N. H. \& Pusztai, A. (1982). Journal of the Science of Food and Agriculture 33, $1324-1326$.

Greibel, C. (1950). Zeitschrift fur Lebensmittel-Undersuchung Und-Forschung 90, 191-197.

Jaffe, W. G. (1969). Toxic Constituents of Plant Foodstuffs, pp. 69-74 [I. E. Leiner, editor]. New York: Academic Press.

Jaffe, W. G. (1980). Toxic Constituents of Plant Foodstuffs, pp. 73-102 [I. E. Leiner, editor]. New York: Academic Press.

Jaffe, W. G., Brucher, O. \& Palozzo, A. (1972). Zeitschrift fuer Immunitaetsforschung 142S, $439-447$.

Jayne-Williams, D. J. \& Burgess, C. D. (1974). Journal of Applied Bacteriology 37, 149-169.

Laemmli, U.K. (1970). Nature 227, 680-685.

Landsteiner, K. \& Raubitschek, L. (1908). Zentralblatt fur Bakteriologie und Parasitenkie 45, 660-667.

Miller, D. S. \& Bender, A. E. (1955). British Journal of Nutrition 9, 382-388.

Noah, N. D., Bender, A. E., Reaidi, G. B. \& Gilbert, R. J. (1980). British Medical Journal 281, $236-237$.

Palmer, R., McIntosh, A. \& Pusztai, A. (1973). Journal of the Science of Food and Agriculture 24, 937--944.

Pusztai, A., Clarke, E. M. W., King, T. P. \& Stewart, J. C. (1979). Journal of the Science of Food and Agriculture 30, 843-848.

Pusztai, A., Croy, R. R. D., Grant, G. \& Stewart, J. C. (1983). Seed Proteins, pp. 53-82 [J. Daussant, J. Mosse and J. Vaughan, editors]. New York: Academic Press.

Pusztai, A. \& Palmer, R. (1977). Journal of the Science of Food and Agriculture 28, 620-623. 
Plate 1. Sodium dodecyl sulphate-polyacrylamide gel electrophoresis patterns of various bean samples. (a) Lane 1, kidney bean (Phaseolus vulgaris var. Processor) + cytochrome c; lane 2, runner bean (Phaseolus coccineus); lane 3, lima-bean sample no. 1 ; lane 4 , runner bean. (b) Lane 1, kidney bean + cytochrome $c$; lane 2, lima-bean sample no. 1; lane 3 , baby lima bean; lane 4 , butter-bean sample no. 1; lane 5 , sultani bean; lane 6 , lima or butter bean (Phaseolus lunatus); lane 7, Phaseolus leucanthius; lane 8, lima-bean sample no. 3; lane 9, lima-bean sample no. 2; lane 10, butter-bean sample no 2; lane 11, zebra bean (Phaseolus zebra); lane 12, pinto bean (Phaseolus vulgaris); lanes 13-19, tepary bean (Phaseolus acutifolius); lane 20, kidney bean +cytochrome $c$. 

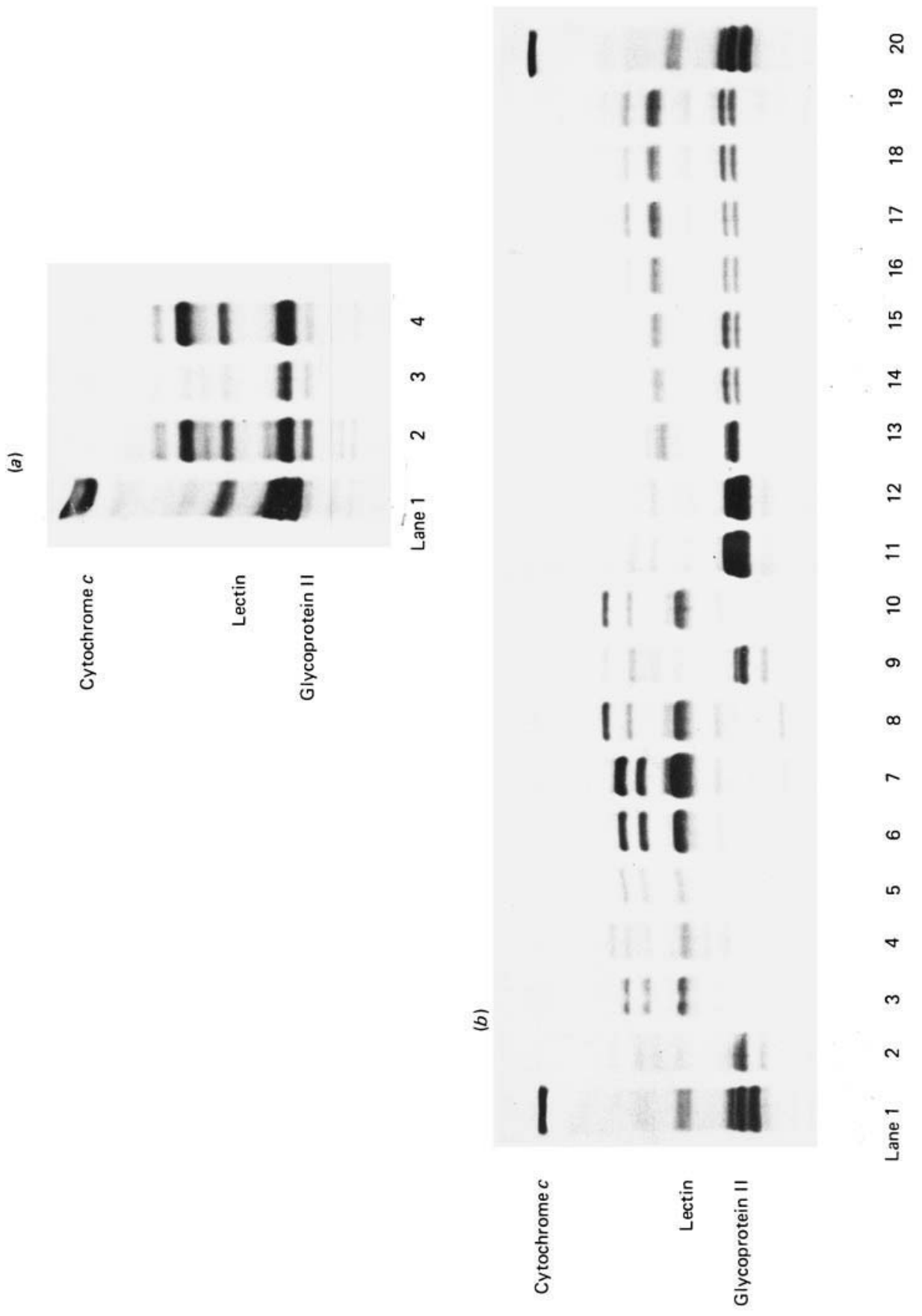